\title{
Block Dosage Form
}

National Cancer Institute

\section{Source}

National Cancer Institute. Block Dosage Form. NCI Thesaurus. Code C42891.

A solid or semi-solid in the shape of a square or rectangle. 